Document downloaded from:

http://hdl.handle.net/10251/69073

This paper must be cited as:

Reig Riera, MM.; Aristoy, M.; Toldra, F. (2013). Variability in the contents of pork meat nutrients and how it may affect food composition databases. Food Chemistry. 140(3):478482. doi:10.1016/j.foodchem.2012.11.085.

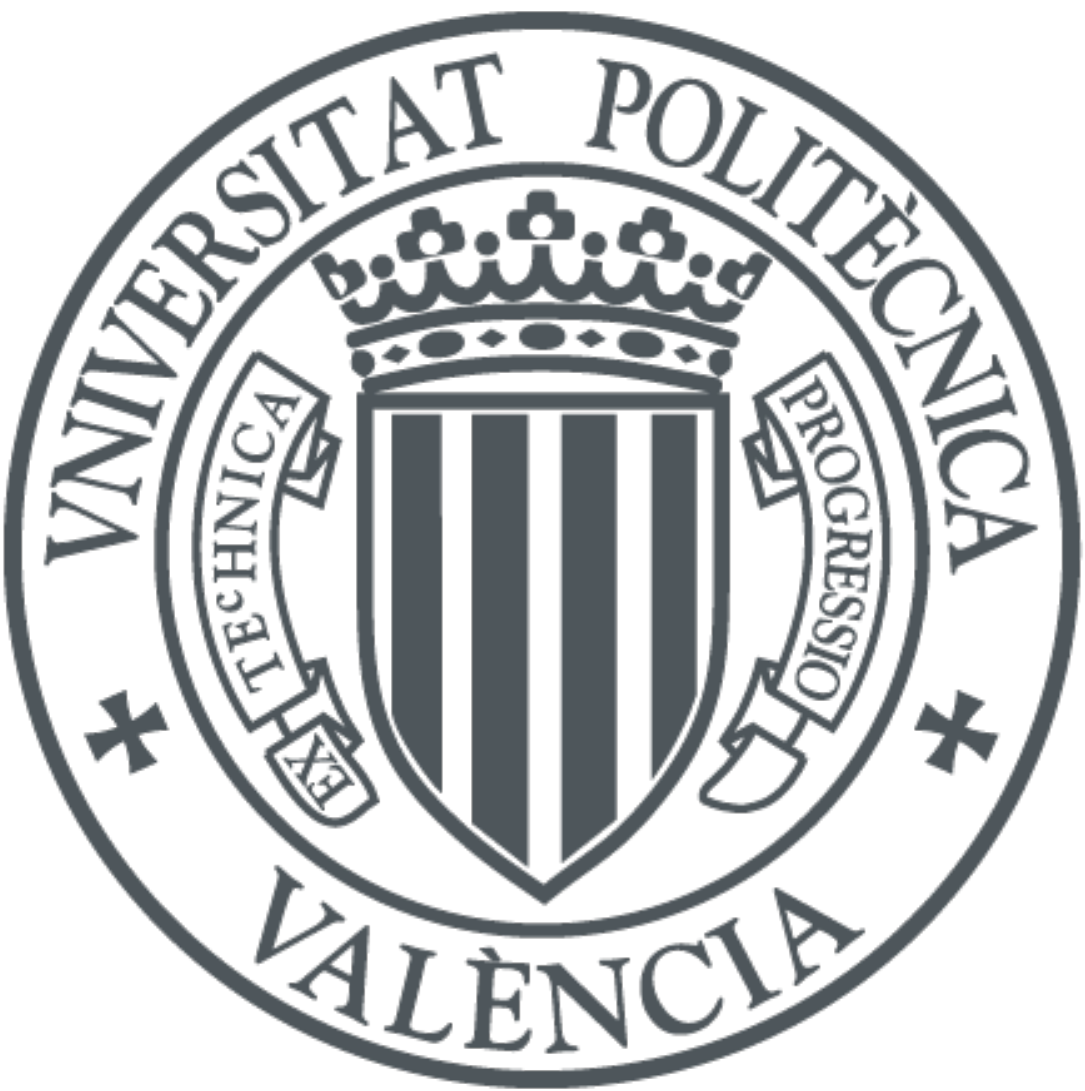

The final publication is available at

http://dx.doi.org/10.1016/j.foodchem.2012.11.085

Copyright Elsevier

Additional Information 


\section{VARIABILITY IN THE CONTENTS OF PORK MEAT NUTRIENTS AND HOW IT MAY AFFECT FOOD COMPOSITION DATABASES}

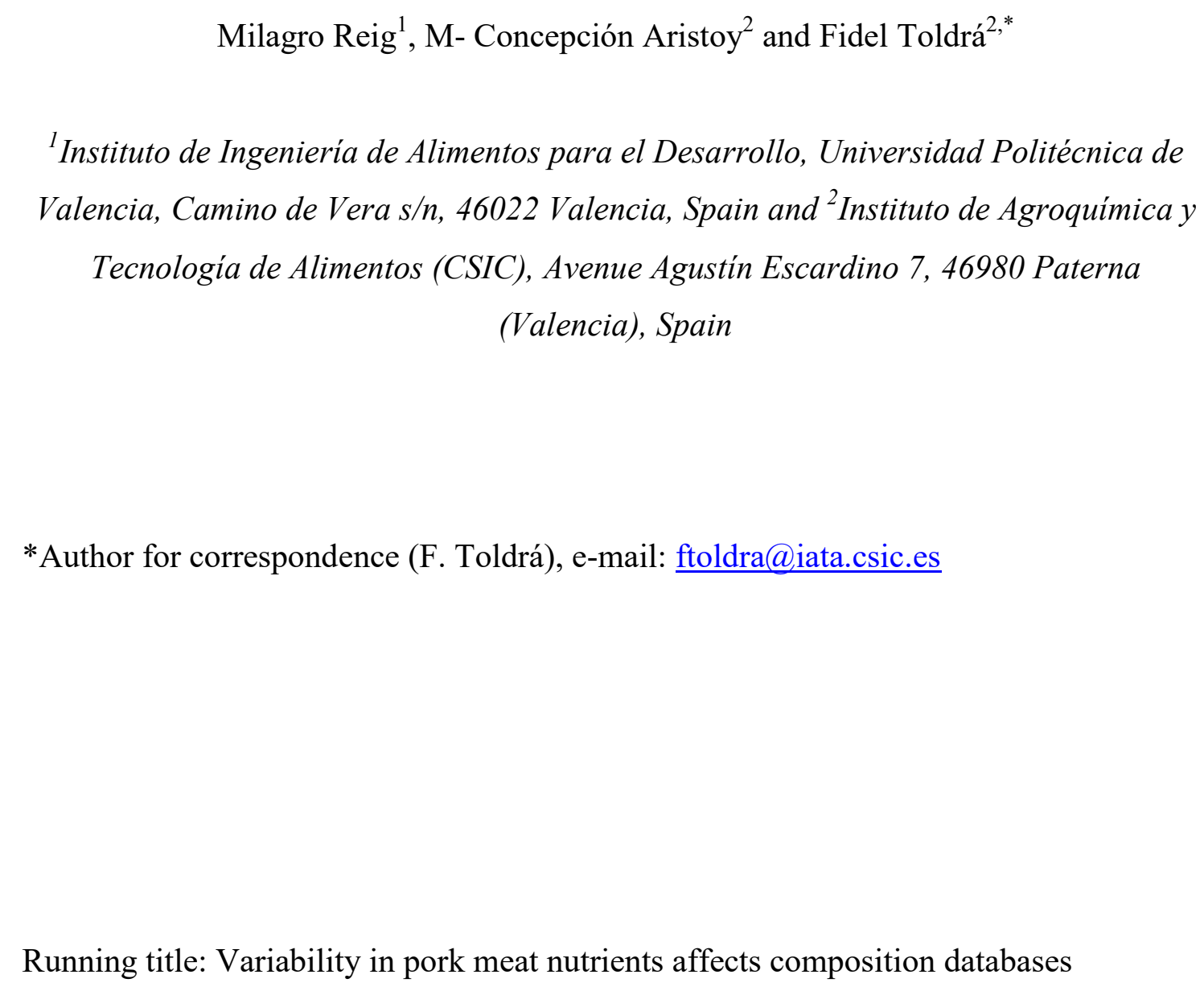

Running title: Variability in pork meat nutrients affects composition databases 


\section{Abstract}

2

3 Pork meat is generally recognised as a food with relevant nutritional properties because

4 of its content in high biological value proteins, group B vitamins, minerals especially

5 heme iron, trace elements and other bioactive compounds. But pork meat also

6 contributes to the intake of fat, saturated fatty acids, cholesterol, and other substances

7 that, in inappropriate amounts, may result in negative physiologically effects. However,

8 there are relevant factors affecting the content of many of these substances and

9 somehow such variability should be taken into consideration. So, genetics, age and even

10 type of muscle have a relevant influence on the amount of fat and the contents in heme

11 iron. Also the composition in fatty acids of triacylglycerols is very sensitive to the

12 contents of cereals in the feed; for instance, polyunsaturated fatty acids may range from

1310 to $22 \%$ in pork meat. The content of other nutrients, like vitamins $\mathrm{E}$ and $\mathrm{A}$, are also

14 depending on the type of feed. Some bioactive substances like coenzyme Q10, taurine,

15 glutamine, creatine, creatinine, carnosine and anserine show a large dependence on the

16 type of muscle. This manuscript describes the main factors affecting the composition of

17 pork meat nutrients and how these changes may affect the general food composition

18 databases.

21 Keywords: pork meat, meat nutrients, fat, fatty acids, vitamins, bioactive substances 


\section{Introduction}

2

3 Pork meat is generally recognised as a food with relevant nutritional properties because

4 of its high content in proteins of high biological value, rich in essential amino acids, as

5 well as group B vitamins, minerals especially heme iron, trace elements and other

6 bioactive compounds (Kauffman, 2001). But pork meat also contributes to the intake of

7 fat, saturated fatty acids, cholesterol, and other substances that, in inappropriate

8 amounts, may result in negative physiologically effects (Toldrá \& Reig, 2011). It is thus

9 of outmust importance to reflect the composition of pork meat as exactly as possible in

10 databases. However, there are relevant factors in pigs breeding and management that

11 affect the content of many of these substances in the resulting meat and somehow such

12 variability should be taken into consideration.

13 The proximate composition of pork meat and its main nutrients (vitamins, minerals,

14 fatty acids, amino acids), either in raw meat or after being cooked through different

15 ways of cooking, are given in most databases (USDA, 2010; Danish Food Composition

16 database, 2009; McCance \& Widdowson, 2011). However, the large natural variability

17 in meat nutrients is not well reflected in most food databases. The identification of the

18 meat is rather vague, usually including scarce information like the animal species, cut

19 and sometimes the muscle, and if either raw or cooked. For instance, some typical

20 descriptions in databases include terms like pork, fresh, backfat, raw or pork, fresh,

21 enhanced, loin, top loin (chops), boneless, separable lean only, raw (USDA, 2010), or

22 pork, rib steaks, raw (Danish Food Composition Database, 2009), or pork, loin steaks,

23 raw, lean and fat (McCance \& Widdowson, 2011).

24 The composition of meat and its contents in nutrients depends on many factors such as:

25 i) breed and genotype, ii) age, iii) sex, iv) production system, v) type of feed and its 
1 composition, and vi) specific cuts/muscles. All of them affect many characteristics of

2 pork meat (Toldrá, 2006) like: i) physical characteristics (weight, colour, intramuscular

3 fat,....), ii) yield (carcass weight, external fat, ratio lean/fat,...), iii) sensory quality, iv)

4 chemical composition (fat, fatty acids, protein, moisture, vitamins, heme iron..) and v)

5 enzyme profile (proteases, lipases, inhibitors,...) and vi) biochemical composition

6 (peptides, amino acids, nucleotides,...). An example on how fat content may vary is

7 shown in figure 1 where the different types of fat (intermuscular, intramuscular and

8 adipose tissue) are indicated. So, the total fat content will vary from cut to cut

9 depending on the relative amounts for the 3 types of fat.

10 The purpose of this manuscript is to show how several factors intrinsic to the origin of

11 pork meat are affecting its nutrients composition and how they may affect the general

12 food composition databases.

14 Effects of breeding, sex and age

16 Pig breeding schemes are usually based on a backcross or on a three- or four-way cross

17 where the sow is a Landrace $\mathrm{x}$ Large White crossbreed and the terminal sire depends on

18 the desired profitability per animal. Some of them, like Belgian Landrace and Pietrain,

19 are used when lower fat and heavily muscled pigs are desired but are quite susceptible

20 to stress giving characteristic exudative meats, also known as PSE (pale, soft,

21 exudative). On the other hand, when the terminal sire is Duroc, pigs grow faster with a

22 better feed conversion ratio but tend to accumulate an excess of fat, especially

23 subcutaneous fat and total lipids as reflected in Table 1 (Toldrá, Reig, Hernández \&

24 Navarro, 1996; Armero, Flores, Toldrá, Barbosa, Olivet, Pla \& Baselga, 1999). The

25 nutritional profile also changes considerably between these terminal sires, with a large 
1 variability in the content of intramuscular fat that may be even double (Leclerq, 1990)

2 and adipose tissue as reflected in table 1. The fatty acid composition of phospholipids

3 has been also reported to change depending on the sire genetic type (Armero, Navarro,

$4 \quad$ Nadal, Baselga \& Toldrá, 2002)

5 The amount of separable fat in the untrimmed raw retail meats have been considerably

6 reduced in the last decades as a consequence of the demand for lower fat cuts and thus,

7 the choice of the terminal sire is a delicate decision that strongly affects carcass

8 conformation, meat composition and meat quality (Toldrá, Rubio, Navarro \& Cabrerizo,

9 2004). It must be remarked that leaner carcasses are generally associated with a higher

10 content of glycolytic muscle fibres, characterised by faster postmortem metabolism,

11 pale meat colour and lower water holding capacity (De Smet, Claeys \& Demeyer,

12 2002).

13 The exercise also has some effect on the tissue lipid composition. It has been reported

14 that pigs maintained in free-range conditions in the Mediterranean forest had

15 subcutaneous and intramuscular fats with higher monounsaturated fatty acids and lower

16 saturated fatty acids than those pigs housed individually and receiving acorns as feed

17 (Dazza, Rey, Olivares, Cordero, Toldrá \& López-Bote, 2009). The subcutaneous fat

18 depth increases with exercise being $15.9 \mathrm{~mm}$ for exercised pigs in comparison to 11.5

$19 \mathrm{~mm}$ depth for those kept in confinement (Purchas, Morel, Janz \& Wilkinson, 2009). The

20 same applies for the intramuscular fat content where $3.36 \%$ for extensive vs $1.44 \%$ for

21 intensive raised pigs have been reported in the semimembranosus muscle (Purchas et

22 al., 2009).

23 The effects of sex are not so relevant but also affect the fat content because thinner

24 subcutaneous fat layers are observed in males because of the differences in sex hormone

25 metabolism between males and females (Nürmberg, Wegner \& Ender, 1998). So, the 
1 meat from barrows typically contain more fat and marbling and a thicker subcutaneous

2 fat layer than meat from gilts (Armero et al, 1999). If castration is eliminated, the fat

3 content in boars is reduced and getting proximate to that of gilts (Bass, Butler-Hogg \&

4 Kirton, 1990).

5 The age of the pigs is significantly correlated with an increased adipose tissue and

6 subcutaneous fat thickness content (higher calorie intake) and also an expanded

7 development of connective tissue and more content of myoglobin which contains heme

8 iron (Hugo and Roodt, 2007). The longissimus dorsi muscle of 8-month-old pigs (130

$9 \mathrm{~kg}$ weight), as compared to 6-month-old pigs (100 kg), was reported to have less water,

10 more proteins and more intra-muscular fat whereas collagen concentration was similar

11 (Candek-Potokar, Hender, Lefaucheur \& Bonneau, 1998). Younger pigs tend to deposit

12 more unsaturated lipids while older pigs predominate in saturated lipids (Hugo and

13 Roodt, 2007). The age also affects the muscle enzyme activity tending to have a higher

14 peptidase to proteinase ratio and higher lipase activity in older pigs (Toldrá, Flores,

15 Aristoy, Virgili \& Parolari, 1996).

\section{Effect of feed}

18

19 An excess of feed increases the amount of intramuscular fat but if animals are deprived of

20 feed, lipolysis may be induced and the amount of fat reduced, especially in glycolytic

21 muscles (Fernández, Mourot, Mounier \& Ecolan, 1995).

22 Due to the monogastric nature of pigs, the feed exerts a relevant effect on the composition

23 of pork meat, not only in the amount of fat but also on its composition in fatty acids.

24 Dietary fatty acids are incorporated practically unchanged into the adipose tissue and

25 cellular membranes, where desaturation and chain elongation processes may occur (Toldrá

26 et al. 1996a, Jakobsen, 1999). The extent of incorporation may vary depending on the

27 specific fatty acid and the type of feed. Different types of cereals as well as dietary oils 
1 and their effects on the proportions in fatty acid composition have been studied. The use

2 of canola or linseed oils produce a substantial increase in the content of linolenic acid

3 (C 18:3), and slightly increase the eicosapentaenoic (EPA, C 22:5) and docosahexaenoic

4 (DHA, C 22:6) acid contents in pork meat, which are all n-3 fatty acid, and furthermore

5 also decreasing the linoleic acid content. (Jiménez-Colmenero, Reig \& Toldrá, 2006).

6 So, the n-6:n-3 ratio can be reduced from values higher than 9 towards less than 5 which

7 is closer to the recommended maximum value of 4 (Enser, Richardson, Wood, Gill \&

8 Sheard, 2000). Other dietary oils such as soya, peanut, corn, and sunflower increase the

9 content of linoleic acid (C 18:2), an n-6 fatty acid. Although it increases the total PUFA

10 content, this fatty acid does not contribute to decrease the n-6:n-3 ratio, just the reverse.

11 Higher PUFA:SFA ratios (around 0.6-0.7) and n-6:n-3 ratios near 2.0 have been

12 obtained when feeding either linseed oil alone or a mixture of linseed and olive oils (see

13 Table 2) (Hoz, López-Bote, Cambero, D'Arrigo, Pin, Santos \& Ordóñez, 2003). The

14 addition of fish oils or algae substantially increases the content in EPA and DHA and

15 sensibly reduces the n-6:n-3 ratio to near 2 (Jakobsen, 1999, Irie and Sakimoto, 1992)

16 even though the presence of vitamin E to prevent any oxidation (Marriott, Garrett, Sims,

17 wang \& Abril, 2002).

18 When feeds are rich in saturated fats like tallow, the levels of palmitic, palmitoleic, stearic

19 and oleic acids in pork meat are substantially higher and the PUFA:SFA ratio is lower

20 (Morgan, Noble, Cocchi \& McCartney, 1992; Leszczynski, Pikul, Easter, McKeith,

21 McLaren, Novakofski, Bechtel \& Jewell, 1992). Feeds rich in linoleic acid (C 18:2), a n-

226 atty acid typically present in soy, maize, sunflower and barley, significantly increase

23 the concentration of this fatty acid in meat (Larick, Turner, Schoenherr, Coffey \&

24 Pilkington, 1992; Toldrá et al., 2004) (see Table 2) but it is partly replacing the oleic

25 acid content (Hernández et al., 1998). 
1 The content in conjugated linoleic acid (CLA) may also vary depending on the type of

2 feed. Studies have been performed on supplementing CLA to pigs with the goal to

3 increase its presence in pork meat in view of the potential benefits for consumers like

4 anticancerinogenic, antidiabetic and antiatherogenic effects (Lauridsen \& Henckel,

5 2005; Schmid, Collomb, Sieber \& Bee, 2007). For example, Large White pigs

6 supplemented with a diet containing 2\% CLA enriched oil were reported to contain 14.9

$7 \mathrm{mg} \mathrm{CLA} / \mathrm{g}$ fatty acids in the adipose tissue while control pigs with feeding linoleic acid

8 enriched oil did not show detectable CLA levels (Bee, 2001). Similar results were

9 reported for pigs receiving 1\% CLA that resulted in $5.5 \mathrm{mg}$ CLA/100g fatty acids

10 present in the muscle (Eggert, Belury, Kempa-Steczko, Mills \& Schinckel, 2001).

\section{Effects of muscle metabolism}

Meat cuts are usually composed of various skeletal muscles which contain various types of fibres that differ in contractility, colour, metabolism and other properties (Toldrá and

16 Reig, 2004). The post mortem conversion of muscle to meat involves numerous

17 biochemical reactions directly affected by the type of fibre and its energy metabolism

18 (Toldrá, 2003). So, depending on the relative proportion of certain types of fibres in the 19 muscle, many characteristics of the meat are affected and thus lactic acid generation, $\mathrm{pH}$

20 drop rate, water exudation, and colour development, may vary significantly (Toldrá, 21 2006). Therefore, the metabolic type of the muscle can be considered as a major factor 22 affecting the variability of meat composition as shown in Table 3 where moisture, 23 protein and total lipids, also cholesterol, may change depending on the type of muscle 24 present in the cut (Hernández et al., 1998).

25 The determination of the content of myoglobin and the assay of lactate dehydrogenase 26 (LDH) activity have been used as a good approximation to the type of metabolic 
1 pattern, either glycolytic or oxidative, of the muscle ( Leseigneur-Meynier \& Gandemer, 2 1991; Flores, Alasnier, Aristoy, Navarro, gandemer \& Toldrá, 1996). In fact, the

3 myoglobin content is closely related to the oxidative pattern of the muscle, running in

4 parallel with its red colour intensity. Lactate dehydrogenase activity is an indicator of

5 the muscle glycolytic potential. Based on these values (myoglobin content and LDH

6 activity), muscles like longissimus dorsi, semimembranosus and biceps femoris are

7 classified as predominantly glycolytic muscles while other muscles like masseter can be

8 considered as predominatly oxidative (Flores et al. 1996). There are some muscles

9 laying in an intermediate situation like Trapezius (Leseigneur-Meynier and Gandemer,

10 1991). Some examples of variation among muscles for substances discussed below are

11 given in Table 4.

12 The content of natural antioxidant dipeptides carnosine and anserine in pork muscle was

13 reported to be significantly lower in oxidative muscles (Aristoy \& Toldrá, 1998; Cornet

14 and Bousset, 1998), who also demonstrated the relationship of the metabolic type of

15 fibres with the content of several amino acids in muscle. For instance, the content of

16 taurine, glutamine and free lysine were significantly higher content in oxidative muscles

17 trapezius and masseter (see Table 4).

19 Creatine is a key substance in the muscle, particularly involved in the transfer of high 20 energy phosphate to ADP in muscle cells (Wyss \& Kaddurah-Daouk, 2000). Creatine 21 has also been reported to improve muscle performance (Demant \& Rhodes, 1999).

22 Creatine turns into creatinine in meat through a heating-catalysed, non-enzymatic 23 conversion. The contents of creatine and creatinine were analysed by hydrophilic 24 interaction chromatography in seven pork muscles of different metabolic type 25 (semimembranosus, biceps femoris, gluteus maximus, longissimus dorsi, Gluteus 
1 medius, trapezius and masseter) (Mora, Sentandreu \& Toldrá, 2008). Both substances

2 showed a relationship between the creatine and creatinine content and the type of

3 muscle metabolism (see Table 4), with a general trend towards significantly higher

4 concentrations $(\mathrm{p}>0.95)$ in those muscles like semimembranosus, biceps femoris,

5 gluteus maximus and longissimus dorsi which are characterised by glycolytic

6 metabolism. On the other hand, an oxidative muscle like masseter, was characterised by

7 the lowest contents of creatine and creatinine while muscles with intermediate

8 metabolism like gluteus medius and trapezius, were reported to have intermediate

9 contents (Mora et al., 2008).

10

11

\section{Incorporation of functional ingredients through the feed}

A large number of functional ingredients have been assayed during the last decade and added to different foods, including pork meat, to increase its functional value for consumers. The effect of these ingredients added to pork meat may vary depending on the type of animal breeding and production. Some of these bioactive substances are added to feeds in order to get them accumulated into the pigs muscles and then, present in the resulting meat (Lynch and Kerry, 2000). This is the case of specific fatty acids like omega-3 fatty acids, other unsaturated fatty acids, selenium and vitamin E (Sheard, Enser, Wood, Nute, Gill \& Richardson, 2000; Morel, Janz, Zou, Purchas, Hendriks \& Wilkinson, 2008; Zhang, Xiao, Samaraweera, Lee \& Ahn, 2010). Many studies have been performed for the incorporation of omega-3 fatty acids in meat because of their ability to reduce the levels of low density lipoprotein (LDL) cholesterol and blood triacylglycerols (Harris, 2007). However, it is necessary to add antioxidants (i.e. vitamin E) because these fatty acids are prone to oxidation (Jiménez-Colmenero, Carballo \& Cofrades, 2001). Other acids like the conjugated linoleic acid (its isomers 
1 cis-9-trans-11 and trans-10,cis-12) has been reported to exert relevant biological

2 activities (Park, 2009) and can be added in the feed (Schmid et al., 2006). The

3 enrichment in CLA has been reported to reduce the intramuscular cholesterol

4 (Lauridsen et al., 2005).

5 The natural content in vitamins $\mathrm{A}, \mathrm{D}, \mathrm{C}$ and $\mathrm{E}$ is poor in pork meat (Reig and Toldrá, 6 1998). Vitamin E ( $\alpha$-tocopheryl acetate), which was studied in depth in the 1990s, is a

7 very effective antioxidant because it is accumulated in tissues and subcellular structures,

8 including membranes. Vitamins E and A may be enriched in pork muscle through its

9 supplementation in the feed. Depending on the concentration (typically around 100-200

$10 \mathrm{mg} / \mathrm{kg}$ feed) and time of supplementation (several weeks prior slaughtering) the content of

11 such vitamins may be proportionally increased in the muscles (Mercier, Gatellier, Viau,

12 Remignon \& Renerre, 1998). Typical values near $13 \mathrm{mg} / \mathrm{kg}$ dry muscle may be reached

13 (Isabel et al., 2003). Vitamin E tend to be mainly distributed in the muscles of the thoracic

14 limb, neck and thorax (O’Sullivan, Kerry, Buckley, Lynch \& Morrisey, 1997).

15 The content of iron in pork meat is quite relevant as well as its content in trace elements

16 like selenium, magnesium and zinc. Iron content is higher in oxidative than in glycolytic

17 muscles (Aristoy and Toldrá, 1998). The selenium content in meat may be enriched

18 through supplementation with sodium selenite or selenium-rich yeast. The content in

19 magnesium may also depend on the diet and the type of salts added, such as magnesium

20 aspartate, magnesium aspartate hydrochloride or magnesium fumarate (D'Souza,

21 Warner, Dunshea \& Leury, 1999).

24 Conclusions 
1 There are many variables affecting the composition of meat and its contents in nutrients,

2 some of them are not well reflected in most food databases. It would be advisable to

3 include better description of the analysed meats including, at least, the breed or

4 crossbreed, the age, the type of production system and main ingredients present in the

5 feed. All these data should be present in the commercial labelling of pork meat cuts for

6 a full description of its content and a better comprehensive description of its

7 composition and nutritional relevance for consumers.

8

9 Acknowledgements

11 Grant AGL2010-16305 from the Spanish Ministry of Science and Innovation (Madrid, 12 Spain) and FEDER funds and collaboration of Vaquero Foundation for $\mathrm{R}+\mathrm{D}$ on Pork 13 Meat (Madrid, Spain) are acknowledged. Work prepared within the Unidad Asociada 14 IAD (UPV)-IATA (CSIC) framework.

16 References

17 Armero, E., Flores, M., Toldrá, F., Barbosa, J.A., Olivet, J., Pla, M., Baselga, M. 18 (1999). Effects of pig sire types and sex on carcass traits, meat quality and sensory 19 quality of dry-cured ham. Journal of the Science of Food and Agriculture, 79: 1147201154.

21 Armero, E., Navarro, J.L., Nadal, M.I., Baselga, M., Toldrá, F. (2002) Lipid composition 22 of pork muscle as affected by sire genetic type. Journal of Food Biochemistry, 26:91-102. 23 Aristoy, M.C., Toldrá, F. (1998) Concentration of free amino acids and dipeptides in 24 porcine skeletal muscles with different oxidative patterns. Meat Science, 50: 327-332. 
1 Bass, J.J., Butler-Hogg, B.W., Kirton, A.H. (1990) Practical methods of controlling

2 fatness in farm animals. In: Reducing fat in meat animals; Wood, J.D., Fischer, A.V.

3 Eds.; London, UK: Elsevier Applied Science, 398-436.

4 Bee, G. (2001) Dietary conjugated linoleic acids affect tissue lipid composition but not de

5 novo lipogenesis in finishing pigs. Animal Research, 50, 383-399.

6 Candek-Potokar, M., Ilender, B., Lefaucheur, L., Bonneau, M. 1998. Effects of Age

7 and/or Weight at Slaughter on longissimus dorsi Muscle: Biochemical Traits and

8 Sensory Quality in Pigs. Meat Science, 48, 3/4, 287-300,

9 Cornet, M., Bousset, J. (1999) Free amino acids and dipeptides in porcine muscles:

10 differences between red and white muscles. Meat Science, 51, 215-219.

11 Danish Food Composition database (2009) The official Danish Food Composition

12 Database. www.foodcomp.dk/fcdb_default.asp. Accessed august 2011

13 Dazza, A., Rey, A.I., Olivares, A., Cordero, G., Toldrá, F., López-Bote, C.J. (2009).

14 Physical activity-induced alterations on tissue lipid composition and lipid metabolism in

15 fattening pigs. Meat Science, 81. 641-646.

16 Demant, T.W., Rhodes, E.C. (1999). Effects of creatine supplementation on exercise 17 performance. Sports Medicine, 28, 49-60.

18 De Smet, S., Claeys, E., Demeyer, D. (2002). Muscle enzymes in relation to meat 19 quality and muscularity. In: Research advances in the quality of meat and meat 20 products. Toldrá, F. Ed.; Trivandrum, India: Research Signpost, pp. 123-142.

21 D’Souza, D.N., Warner, R.D., Dunshea, F.R., Leury, B.J. (1999). Comparison of different 22 dietary magnesium supplements on pork quality. Meat Science, 51, 221-225.

23 Eggert, J.M., Belury, MA., Kempa-Steczko, A., Mills, S.E., Schinckel, A.P. (2001).

24 Effects of conjugated linoleic acid on the belly firmness and fatty acid composition of 25 genetically lean pigs. Journal of Animal Science, 79, 2866-2872. 
1 Enser, M., Richardson, R.I., Wood, J.D., Gill, B.P., Sheard, P.R. ( 2000). Feeding linseed

2 to increase the n-3 PUFA of pork: Fatty acid composition of muscle, adipose tissue, liver

3 and sausages. Meat Science, 55, 201-212.

4 Fernández, X., Mourot, J., Mounier, A., Ecolan, P. (1995). Effect of muscle type and

5 food deprivation for 24 hours on the compoisition of the lipid fraction in muscles of

6 Large White pigs. Meat Science, 41:335-343.

7 Flores, M., Alasnier, C., Aristoy, M.C., Navarro, J.L., Gandemer, G., Toldrá, F. (1996).

8 Activity of aminopeptidase and lipolytic enzymes in five skeletal muscles with various

9 oxidative patterns. Journal of the Science of Food \& Agriculture, 70, 127-130.

10 Harris, W.S. (2007) International recommendations for consumption of long chain

11 omega-3 fatty acids. Journal of Cardiovascular Medicine, 8, S50-S52.

12 Hernández, P., Navarro, J.L., Toldrá, F. (1998). Lipid composition and lipolytic enzyme

13 activities in porcine skeletal muscles with different oxidative pattern. Meat Science, 49:1-

$14 \quad 10$

15 Hoz, L., López-Bote, C.J., Cambero, M.I., D’Arrigo, M., Pin, C., Santos, C., Ordóñez, 16 J.A. (2003). Effect of dietary linseed oil and $\alpha$-tocopherol on pork tenderloin (Psoas 17 major) muscle. Meat Science, 65, 1039-1044.

18 Hugo, A., Roodt, E. (2007). Significance of porcine fat quality in meat technology: a 19 review. Food Reviews International 23, 175-198.

20 Irie, M., Sakimoto, M. (1992). Fat characteristics of pigs fed fish oil containing 21 eicosapentaenoic and docosahexanoic acids. Journal of Animal Science, 70, 470-477.

22 Isabel, B., López-Bote, C.J., Hoz, L., Timón, M., García, C., Ruiz, J. (2003) Effects of

23 feeding elevated concentrations of monounsaturated fatty acids and vitamin $\mathrm{E}$ to swine 24 on characteristics of dry-cured hams. Meat Science, 64, 475-482. 
1 Jakobsen, K. (1999). Dietary modifications of animal fats: status and future

2 perspectives. Fett/Lipid, 101, 475-483.

3 Jiménez-Colmenero, F., Reig, M., Toldrá, F. (2006). New approaches for the

4 development of functional meat products. In: L.M.L. Nollet \& F. Toldrá (Eds.),

5 Advanced Technologies for Meat Processing, (pp. 275-308), Boca Raton, Fl, CRC

6 Press.

7 Jiménez Colmenero, F., Carballo, J., Cofrades S. (2001). Healthier meat and meat 8 products: their role as functional foods. Meat Science, 59, 5-13.

9 Kauffman, R.G. (2001). Meat composition. In: Meat Science and Applications (YH Hui,

10 WK Nip, RW Rogers, OA Young, Eds), pp. 1-19, New York: Marcel Dekker, Inc.

11 Larick, D.K., Turner, B.E., Schoenherr, W.D., Coffey, M.T., Pilkington, D.H. (1992)

12 Volatile compound contents and fatty acid composition of pork as influenced by linoleic 13 acid content of the diet. Journal of Animal Science, 70, 1397-1403.

14 Lauridsen, C., Mu, H., Henckel, P. (2005) Influence of dietary conjugated linoleic acid

15 (CLA) and age at slaughtering on performance, slaughter- and meat quality,

16 lipoproteins, and tissue deposition of CLA in barrows. Meat Science 69, 393-399.

17 Leclerq, B. (1990) Facteurs influençant la teneur en lipids des viands de porc et de 18 volailles. Viandes Produits Carnées, 11, 250-254.

19 Leseigneur-Meynier, A., Gandemer, G. (1991). Lipid-Composition of Pork Muscle in

20 Relation to the Metabolic Type of the Fibers. Meat Science, 29, 229-241.

21 Leszczynski, D.E., Pikul, J., Easter, R.A., McKeith, F.K., McLaren, D.G., Novakofski, 22 J., Bechtel, P.J., Jewell, D.E. (1992) Characterization of lipid in loin and bacon from 23 finishing pigs fed full-fat soybeans or tallow. Journal of Animal Science, 70, 2175242181. 
8 McCance and Widdoson (2011) McCance \& Widdowson's Composition of Foods

$9 \quad$ Integrated Dataset. Accessed august 2011

10 Mercier, Y., Gatellier, P., Viau, M., Remignon, H., Renerre, M. (1998) Effect of dietary

11 fat and vitamin $\mathrm{E}$ on colour stability and on lipid and protein oxidation in turkey meat

12 during storage. Meat Science, 48, 301-318.

13 Mora, L., Sentandreu, M.A., Toldrá, F. (2008) Contents of creatine, creatinine and

14 carnosine in pork muscles of different metabolic type. Meat Science, 79, 709-715.

15 Morel, P.C., Janz, J.A., Zou, M., Purchas, R.W., Hendriks, W.H., Wilkinson, B.H.

16 (2008) The influence of diets supplemented with conjugated linoleic acid, selenium and

17 vitamin E, with or without animal protein, on the composition of pork from female pigs.

18 Journal of Animal Science, 86, 1145-1155.

19 Morgan, C.A., Noble, R.C., Cocchi, M., McCartney, R. (1992) Manipulation of the fatty

20 acid composition of pig meat lipids by dietary means. Journal of the Science of Food and

21 Agriculture, 58, 357-368.

22 Nürmberg, K., Wegner, J., Ender, K. 1998. Factors influencing fat composition in

23 muscle and adipose tissue of farm animals. Livestock Production Science 56, 145-156. 
8 from New Zealand and Singapore. Meat Science 81, 540-548.

9 Reig, M., Toldrá, F. (1998) Pork meat as a source of vitamins. Recent Research

10 Developments in Nutrition, 2, 29-34.

11 Schmid, A., Collomb, M., Sieber, R., Bee, G. (2006) Conjugated linoleic acid in meat

12 and meat products: a review. Meat Science, 73, 29-41.

13 Sheard, P.R., Enser, M., Wood, D.J., Nute, G.R., Gill, B.P., Richardson, R.I. (2000)

14 Shelf life and quality of pork and pork products with raised n-3 PUFA. Meat Science, $15 \quad 55,213-221$.

16 Toldrá, F., Flores, M., Aristoy, M.C., Virgili, R., Parolari, G. (1996a) Pattern of muscle

17 proteolytic and lipolytic enzymes from light and heavy pigs. Journal of the Science of

18 Food and Agriculture, 71, 124-128.

19 Toldrá, F., Reig, M., Hernández, P., Navarro, J.L. (1996b) Lipids from pork meat as 20 related to a healthy diet. Recent Research Developments in Nutrition, 1, 79-86.

21 Toldrá, F., Rubio, M.A., Navarro, J.L., Cabrerizo, L. (2004) Quality aspects of pork 22 and its nutritional impact. In: Quality of Fresh and Processed Foods. 23 Advances in Experimental Medicine and Biology. F. Shahidi, A.M. Spanier, 24 C-T. Ho, T Braggins, Eds.; Vol. 542, New York: Kluwer Academic/Plenum Publ, 252532. 
1 Toldrá, F. (2006). Meat: Chemistry and biochemistry. In: Handbook of Food Science,

2 Technology and Engineering (YH Hui, JD Culbertson, S Duncan, I Guerrero-Legarreta,

3 ECY Li-Chan, CY Ma, CH Manley, TA McMeekin, WK Nip, LML Nollet, MS

4 Rahman, F Toldrá, YL Xiong, Eds.), volume 1, (pp 28-1 to 28-18), , Boca Raton, FL:

5 CRC Press.

6 Toldrá, F., Reig, M. (2004) Analysis of meat in food. In: Handbook of Food Analysis.

7 Nollet, L.M.L., Ed.; New York: Marcel Dekker Inc., 1941-1959.

8 Toldrá, F., Reig, M. (2011) Innovations for healthier processed meats. Trends in Food

$9 \quad$ Science \& Technology, 22, 517-522.

10 USDA (2010) USDA National Nutrient Database for Standard Reference, Release 23.

11 http://www.ars.usda.gov/Services. Accessed august 2011

12 Wyss, M., Kaddurah-Daouk, R. (2000). Creatine and creatinine metabolism.

13 Physiological Reviews, 80, 1107-1213.

14 Zhang, W., Xiao, S., Samaraweera, H., Lee, E.J., Ahn, D.U. (2010). Improving

15 functional value of meat products. Meat Science, 86, 15-31.

LEGENDS FOR THE FIGURES

21 Figure 1.- Pork cut with indication of the different types of fat: intermuscular fat (fat 22 located between muscles), intramuscular fat (located inside a particular muscle) and 23 adipose tissue (external fat). 
Table 1.- Composition in subcutaneous fat (adipose tissue) at the midline of gluteus medius muscle and semimembranosus muscle (expressed in $\mathrm{g} / 100 \mathrm{~g}$ muscle) for 5 different sire genetic types (adapted from

\begin{tabular}{lccccccc}
\hline & \multicolumn{2}{c}{ DU* } & \multicolumn{2}{c}{ LWd } & \multicolumn{3}{c}{ LWe } \\
\hline & X SE & X SE & \multicolumn{2}{l}{ X SE } \\
\hline Moisture & $74.56^{\mathrm{a}}$ & 0.31 & $75.04^{\mathrm{a}, \mathrm{b}}$ & 0.31 & $75.93^{\mathrm{a}}$ & 0.32 & 75 \\
Subcutaneous fat & $8.07^{\mathrm{a}, \mathrm{b}}$ & 0.31 & $7.54^{\mathrm{b}}$ & 0.32 & $8.49^{\mathrm{a}}$ & 0.34 & 8. \\
Total lipids** & $3.23^{\mathrm{a}}$ & 0.28 & $2.08^{\mathrm{b}}$ & 0.23 & $2.35^{\mathrm{b}, \mathrm{c}}$ & 0.31 & 2.2
\end{tabular}

${ }^{\mathrm{a}}$ Different letter indicate significant differences between means $(\mathrm{P}<0.05)$

*Sire types were Danish Duroc (DU), Dutch Large White (LWd), English Large White (LWe), Belgian LandracexLandrace (BLxL mated with LandracexLarge White crossbred sows. **Total lipids are the sum of inter and intramuscular lipids. 
Table 2.- Examples of the effect of main ingredients in feed on the composition of major fatty acids in pork meat.

\begin{tabular}{|c|c|c|c|c|}
\hline Major fatty acids & Barley + soya bean ${ }^{a}$ & Tallow $^{b}$ & $\begin{array}{c}\text { Barley }+ \\
\text { wheat }+ \text { corn }^{c}\end{array}$ & Safflower oil $^{\mathrm{d}}$ \\
\hline C 14:0 & - & 1.37 & 1.55 & - \\
\hline C 16:0 & 23.86 & 24.15 & 25.10 & 27.82 \\
\hline C 18:0 & 10.16 & 11.73 & 12.62 & 12.53 \\
\hline C 16:1 & 3.0 & 3.63 & 2.79 & 3.56 \\
\hline C 18:1 & 39.06 & 46.22 & 36.47 & 37.81 \\
\hline C 20:1 & - & 0.29 & 0.47 & 0.01 \\
\hline C 18:2 & 17.15 & 8.95 & 16.49 & 14.60 \\
\hline C 20:2 & - & 0.44 & 0.49 & 0.01 \\
\hline C 18:3 & 0.91 & 0.26 & 1.14 & 0.01 \\
\hline C 20:3 & 0.21 & 0.25 & 0.30 & 0.01 \\
\hline C 20:4 & 4.26 & 2.13 & 0.25 & 2.14 \\
\hline C 22:5 & 0.64 & - & - & 0.01 \\
\hline C 22:6 & 0.75 & - & - & 0.01 \\
\hline Total SFA & 34.02 & 37.83 & 39.42 & 40.35 \\
\hline Total MUFA & 42.06 & 50.26 & 39.74 & 42.38 \\
\hline Total PUFA & 23.92 & 11.91 & 20.84 & 16.79 \\
\hline PUFA:SFA & 0.70 & 0.32 & 0.53 & 0.42 \\
\hline$n-6: n-3$ & 9.4 & 45.3 & 16.6 & $>100$ \\
\hline
\end{tabular}

${ }^{\mathrm{a}}$ Morgan et al (1992), ${ }^{\mathrm{b}}$ Leszczynski et al (1992), ${ }^{\mathrm{c}}$ Toldrá et al (2004), ${ }^{\mathrm{d}}$ Larick et al (1992), ${ }^{\mathrm{e}}$ Dazza et al (2009) 
Table 3.- Composition of moisture, protein, total lipids and cholesterol (expressed in $\mathrm{g} / 100 \mathrm{~g}$ muscle) in 3 pork muscles with different oxidative patterns (adapted from Hernández et al, 1998).

\begin{tabular}{lcccccc}
\hline Muscle & \multicolumn{2}{c}{$\begin{array}{l}\text { longissimus } \\
\text { dorsi }\end{array}$} & \multicolumn{1}{c}{ biceps femoris } & \multicolumn{2}{c}{ triceps brachii } \\
& \multicolumn{1}{c}{ X } & SD & X & SD & X & SD \\
\hline Moisture & $74.6^{\mathrm{a}}$ & 0.58 & $75.2^{\mathrm{b}}$ & 0.60 & $76.3^{\mathrm{c}}$ & 0.50 \\
Protein & $22.7^{\mathrm{a}}$ & 2.1 & $21.9^{\mathrm{a}, \mathrm{b}}$ & 1.1 & $21.4^{\mathrm{b}}$ & 1.4 \\
Total lipid & $27.0^{\mathrm{a}}$ & 0.22 & $31.5^{\mathrm{b}}$ & 0.36 & $31.5^{\mathrm{b}}$ & 0.52 \\
$\begin{array}{l}\text { Cholesterol } \\
\text { (mg/100g muscle) }\end{array}$ & $46.1^{\mathrm{a}}$ & 5.6 & $52.2^{\mathrm{b}}$ & 7.0 & $51.3^{\mathrm{b}}$ & 8.5 \\
\hline${ }^{\mathrm{a}}$ Different letter indicate significant differences between means $(\mathrm{P}<0.05)$ &
\end{tabular}


Table 4.- Composition of certain nutrients (expressed in $\mathrm{mg} / 100 \mathrm{~g}$ muscle) in 4 pork muscles with different oxidative patterns (adapted from Aristoy and Toldrá, 1998, Mora et al., 2008).

\begin{tabular}{|c|c|c|c|c|}
\hline Muscle & longissium dorsi & semimembranosus & trapezius & masseter \\
\hline & X SD & X SD & X SD & $\begin{array}{ll}X & \text { SD }\end{array}$ \\
\hline Carnosine & $313.0^{\mathrm{a}} \quad 35.6$ & $320.9^{\mathrm{a}} \quad 17.2$ & $181.0^{b} \quad 10.1$ & $21.1^{\mathrm{c}} \quad 1.5$ \\
\hline Anserine & $14.6^{\mathrm{a}} \quad 1.4$ & $17.6^{\mathrm{b}} \quad 1.9$ & $10.7^{\mathrm{c}} \quad 1.0$ & $6.1^{\mathrm{d}} \quad 0.4$ \\
\hline Haem content & $400^{\mathrm{a}} \quad 30$ & $420^{\mathrm{a}} \quad 40$ & $980^{\mathrm{b}} \quad 35$ & $882^{\mathrm{b}} \quad 34$ \\
\hline Coenzyme $Q_{10}$ & $0.52^{\mathrm{a}} \quad 0.01$ & $0.61^{\mathrm{a}} \quad 0.02$ & $0.85^{\mathrm{b}} \quad 0.12$ & $1.63^{\mathrm{c}} \quad 0.25$ \\
\hline Creatine & $351.8^{\mathrm{a}} \quad 16.9$ & $373.8^{\mathrm{b}} \quad 10.9$ & $298.2^{\mathrm{c}} \quad 6.9$ & $274.5^{\mathrm{d}} \quad 4.7$ \\
\hline Creatinine & $8.4^{\mathrm{a}} \quad 1.0$ & $9.1^{\mathrm{b}} \quad 0.2$ & $5.5^{\mathrm{c}} \quad 0.3$ & $3.3^{\mathrm{d}} \quad 0.3$ \\
\hline Taurine & $18.8^{\mathrm{a}} \quad 2.4$ & $22.5^{\mathrm{a}} \quad 1.5$ & $35.7^{\mathrm{b}} \quad 5.6$ & $162.2^{\mathrm{c}} \quad 12.5$ \\
\hline Glutamine & $38.9^{\mathrm{a}} \quad 5.0$ & $26.2^{\mathrm{a}} \quad 3.6$ & $161.8^{\mathrm{b}} \quad 30.1$ & $275.2^{\mathrm{c}} \quad 10.7$ \\
\hline Lysine, free & $2.6^{\mathrm{a}, \mathrm{b}} \quad 0.5$ & $1.9^{\mathrm{a}} \quad 0.5$ & $3.1^{\mathrm{b}} \quad 0.6$ & $3.8^{\mathrm{c}} \quad 0.22$ \\
\hline
\end{tabular}


Figure 1

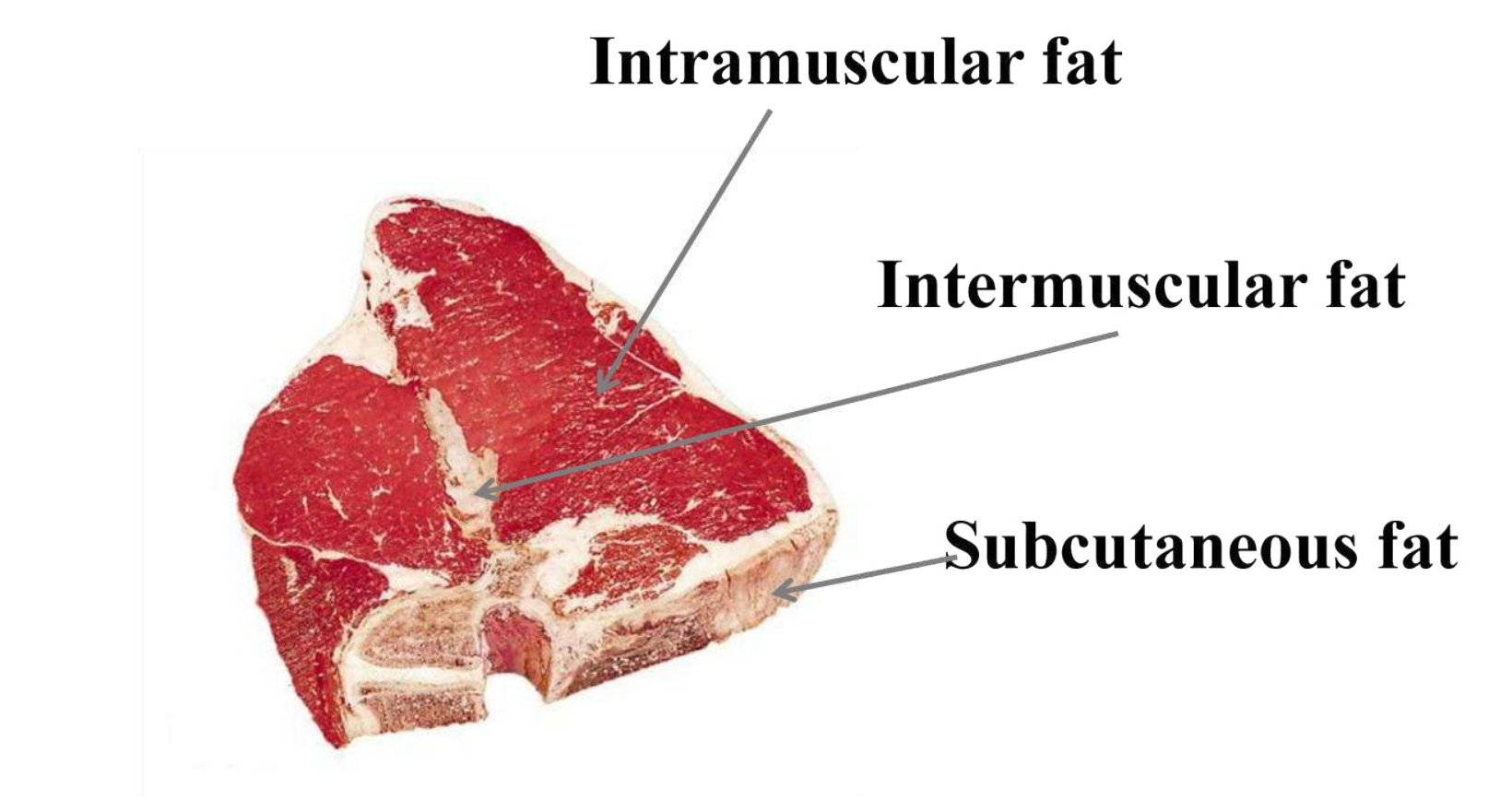

Intramuscular fat

Figure

(1)

.

